\title{
SISTEM PENDUKUNG KEPUTUSAN MENGGUNAKAN METODE PROFILE MATCHIN UNTUK KELAYAKAN PEMBERIAN KREDIT SEPEDA MOTOR (Studi Kasus : Adira Multifinance Kecamatan IV Jurai Painan)
}

\section{Irfan Fadhli, Ahmad Karim, Agung Putra Yunanda, Hilda Rahmawati}

Universitas Pembinaan Masyarakat Indonesia

Email: irfanfadhli74@gmail.com

Email: Ahmadkarimk1973ok@gmail.com

Email: agungputrayunanda69@gmail.com

Email: hildarahma2708@gmail.com

\begin{abstract}
Abstrak
Kredit adalah perjanjian pinjaman uang atau barang antara bank atau lembaga keuangan sebagai kreditur dengan nasabah sebagai debitur dalam jangka waktu tertentu. Untuk menentukan konsumen yang layak diberikan kredit maka diberikan beberapa aspek nilai yang harus dipenuhi oleh calon konsumen. Nilai aspek tersebut dicari oleh suatu sistem pendukung keputusan dengan menggunakan metode profile matcing yang hasilnya akan didapatkan calon konsumen berdasarkan nilai tertinggi untuk memudahkan penelitian nilai aspek tersebut maka sistem pendukung keputusan diimplementasikan ke dalam sebuah aplikasi pemograman PHP dan MySQL. Karenanya para pengambil keputusan tidak perlu mencari secara manual lagi.
\end{abstract}

Kata Kunci: Kredit, Sistem Pendukung Keputusan, Profile Matching
DECISION SUPPORT SYSTEM USING METHODS MATCHIN PROFILE FOR FEASIBILITY OF DELIVERY MOTORCYCLE CREDITS (Case Study: Adira Multifinance Subdistrict IV Jurai Painan)

\begin{abstract}
Credit is a loan agreement money or goods between the bank or the financial institution as a creditor with the costumer as a debitor in specific period. To determine costumers who deserve to be given the credit it granted some aspects of the value that must be met by the prospective costumers. The aspects value are sought by a decision support system using the method of profile matcing that result will get a prospective costumer based on the highest value.To facilitate the research value of these aspects, the decision support system is implemented into an application programming PHP and MySQL. Therefore the decision makers do not need to sought manually again.
\end{abstract}

Keywords: Credit, Decision Support System, Profile Matching 


\section{PENDAHULUAN}

Sistem pendukung keputusan adalah sistem informasi yang membantu untuk megidentifikasi kesempatan pengambilan keputusan atau menyediakan informasi untuk membantu pengambilan keputusan.

Sistem Pendukung keputusan menggunakan metode profile matching merupakan sebuah mekanisme pengambilan keputusan dengan mngasumsikan bahwa terdapat tingkat variabel prediktor yang ideal yang harus dipenuhi oleh subyek yang diteliti, bukannya tingkat minimal yang harus dipenuhi atau dilewati. Dalam pencocokkan profil, dilakukan identifikasi terhadap nasabah yang baik dan yang buruk. Para nasabah tersebut diukur menggunakan beberapa kritreria penilaian. Jika nasabah yang baik memperoleh skor yang berbeda dari nasabah yang buruk atau sebuah karekteristik maka variabel tersebut berfaedah untuk memilih nasabah yang baik. Profil ideal nasabah yang berhasisl dibuat. Misalnya, nasabah yang ideal mungkin memiliki pekerjaan yang tetap, tepat waktu, berkelakuan baik, mampu membayar kredit motor. Dalam pencocokan profil, nasabah yang diberikan kredit adalah nasabah yang mendekati profil ideal seaorang nasabah yang berhasil.

\section{METODE PENELITIAN}

\section{Metode Pengumpulan Data}

Untuk menyelesaikan permasalahan yang ada, metode pengumpulan data yang saya lakukan sebagai penulis adalah dengan cara:

1. Tinjauan Lapangan (Field Reseach)

Pengumpulan data dan informasi dengan melakukan pertemuan langsung dengan Credite Marketing Officier dari Adira multifinance Kecamatan IV Jurai Painan yaitu Jeffry Firmansyah,A.Md. Kemudian melakukan wawancara dengan beberapa pertanyaan yang berhubungan dengan topik yang dibahas kepada pihak-pihak bersangkutan agar penelitian ini berjalan dengan sesuai dengan yang diharapkan.

2. Tinjauan Perpustakaan (Library Reseach)

Dalam metode ini dilakukan pembacaan dan pembelajaran sumber-sumber yang akan mendukung penulisan Skripsi ini. Sumber tersebut dapat berupa buku-buku dan hasil penelitian. Untuk hasil penelitian dapat berupa laporan penelitian, jurnal ilmiah dan skripsi. Termasuk juga kategori bahan-bahan yang dipublikasikan secara on-line (menggunakan internet).

3. Penelitian Laboratorium (Laboratory Reseach).

Penelitian ini dilakukan untuk mengumpulkan data yang dibantu dengan seperangkat Personal Computer (PC). Serta berbagai perangkat lunak yang akan membantu dalam penelitian.

\section{Kerangka Penelitian}


Urutan langkah-langkah yang akan dibuat pada penelitian ini dapat dilihat pada Gambar sebagai berikut:

Gambar 1. Kerangka Kerja Penelitian

\section{HASIL DAN PEMBAHASAN}

\section{Analisa Sistem}

\section{Deskrips Sistem}

Dari hasil pengamatan yang dilakukan oleh penulis, proses pemberian kelayakan kredit sepeda masih kurang, karena masih dilakukan dengan proses manual. Proses penyeleksian harus membutuhkan ketelitian dan waktu yang cukup, karena data nasabah akan dibandingkan dengan standarisasi pencapaian kelayakan pemberian kredit secara satu persatu.

Dengan demikian maka dibutuhkan calon nasabah penerima kredit sepeda motor secara cepat dan tepat. Dalam penelitian ini ada bobot dan aspek yang dibutuhkan untuk menentukan siapa yang terseleks sebagai sebuah sistem yang dapat membantu pihak perusahaan dalam membuat keputusan terhadap penerima kredit. Dengan berbagai macam aspek yang ada, maka pihak perusahaan, tidak kebingungan lagi dalam menentukan calon penerima kredit tersebut. 
Sistem akan mengelola nilai dari jawaban setiap aspek dari data nasabah tersebut. Karena terdapat berbagai macam aspek dan memiliki skala prioritas yang berbeda, maka dibutuhkan suatu metode yang dapat memprosesnya sehingga menghasilkan suatu nilai yang menunjukan alternatif terbaik yang sesuai dengan aspek yang diberikan. Adapun metode yang dapat dipakai untuk menyelesaikan masalah tersebut salah satunya yaitu dengan menggunakan metode profile matching, sehingga berdasarkan aspek-aspek yang diberikan dapat menghasilkan suatu nilai yang menunjukan alternatif terbaik.

\section{Analissa Kebutuhan}

Analisa kebutuhan adalah menganalisis pihak perusahaan untk menentukan kebeutuhan-kebutuhan yang diperlukan oleh sistem tersebut. Adapun petunjuk yang digunakan sebagai bahan untuk menganalisis kebutuhan sistem dengan melakukan wawancara dengan Credit Marketing Officier. Untuk mendapatkan informasi mengenai sistem pendukung keputusan dan kelayakan pemberian kredit sesuai dengan kriteria yang ada.

a. Analisis Kebutuahan Input

Analisis kebutuhan input yaitu data-data nasabah yang sudah memenuhi kriteria kemudian dimaskkan kedalam sistem untuk proses pengambilan keputusan berdasarkan kriteria yang telah ditetapkan.

Kriteria -kriteria yang tela ditetapkan oleh prusahaan yaitu:

a. $\mathrm{C} 1=$ Character : Keterangan yang berisi tentang informasi nasabah

b. $\mathrm{C} 2$ = Capacity : Keterangan yang berisi tentang informasi pekerjaan nasabah

c. $\mathrm{C} 3$ = Cek Lingkungan : Keterangan yang berisi tentang informasi karakter nasabah menurut tetangga sekitar.

b. Analisis Kebutuhan Output

Data keluaran yang dihasilkan adalah sebuah alternatif yang mempunyai nilai tertinggi dibandingkan alternatif nilai yang lain.

Hasil keluaran diambil dari urutan alternatif tertinggi kealternatif terendah. Hasil akhirnya akan ditampilkan oleh program berasal dari setiap nilai kriteria, karena dalam setiap kriteria memeliki nilai yang berbeda- beda. Alternatif yang dimaksud adalah nasabah.

\section{Analisi Kebutuhan Sistem}


Pada analisis proses sistem yang akan dibangun, penggunaan metode profile matching membutuhkan inputan profil nasabah dan profil pencapaian yang merupakan nilai acuan nasabah. Setelah diperoleh profil pencapaian, kemudian dilakukan pemetaan gap kompetensi yang merupakan selisih dari profil nasabah dengan profil pencapaian. Hasil yang didapat dari pemetaan gap akan dilakukan proses pembobotan nilai gap. Kemudian mengelompokan dan menghitung nilai core factor dan secondary factor. Selanjutnya akan dilakukan proses perhitungan nilai total dan rangking nasabah dari urutan tertinggi sampai terendah yang layak untuk menerima kredit sepeda motor.

Berikut adalah langkah-langkah proses penyelesaian menggunakan metode profil matching :

1. Pemetaan Gap Kompetensi

Gap adalah selisih antara profil nasabah dengan profil pencapaian yang ditentukan oleh perusahaan. Pengumpulan gap-gap pada setiap kriteria mempunyai perhitungan yang berbeda-beda.

Rumus untuk pencarian Gap kompetensi:

Gap $=$ Profil Nasabah - Profil Pencapaian

1. Nilai dari tiap aspek dan kriteria yang ditetapkan oleh perusahaan dalam penentuan kelayakan pemberian kredit sepeda motor :

a. Aspek Character dapat dilihat pada tabel 4.1 berikut ini:

Tabel 1 Aspek Character

\begin{tabular}{|l|c|}
\hline \multicolumn{1}{|c|}{ Character } & Bobot \\
\hline KTP/KK asli dan berlaku & 4 \\
\hline Keterangan domisili asli dan berlaku & 3 \\
\hline Dll & 2 \\
\hline
\end{tabular}

b. Aspek Capacity dapat dilihat pada tabel 4.2 berikut ini:

Tabel 2 Aspek Capacity

\begin{tabular}{|l|c|}
\hline Capacity & Bobot \\
\hline PNS & 4 \\
\hline PETANI & 3 \\
\hline Dll & 2 \\
\hline
\end{tabular}


c. Aspek Cek Lingkungan dapat dilihat pada tabel 4.3 berikut ini:

Tabel 3 Aspek Cek Lingkungan

\begin{tabular}{|l|c|}
\hline Cek Lingkungan & Bobot \\
\hline Sopan/Kooperatif & 4 \\
\hline Tidak Sopan & 3 \\
\hline Dll & 2 \\
\hline
\end{tabular}

2. Profile Pencapaian

Penentuan nilai profil pencapaian akan ditentukan oleh pihak sekolah dengan range nilai antara 2 sampai 4. Dari nilai-nilai tersebut akan dilakukan proses perhitungan gap antara nilai profil siswa dengan nilai profil pencapaian.

\section{Perhitungan Menggunakan Metode Profile Matching}

Pada pengujian ini hanya digunakan 5 data calon nasabah baru sesuai dengan kriteria yang telah di tetapkan, dengan data sebagai berikut :

Tabel 4 Nilai Awal Calon Nasabah

\begin{tabular}{|l|l|l|l|l|l|l|l|l|l|l|}
\hline \multirow{2}{*}{ NO } & \multirow{2}{*}{$\begin{array}{l}\text { NAMA } \\
\text { NASABAH }\end{array}$} & \multicolumn{3}{|l|}{ CHARACTER } & \multicolumn{3}{|c|}{ CAPACITY } & \multicolumn{3}{|c|}{ CEK } \\
\cline { 3 - 9 } & A1 & A2 & A3 & B1 & B2 & B3 & C1 & C2 & C3 \\
\hline 1 & ABDUL MUNIR & 4 & 3 & 0 & 4 & 0 & 0 & 4 & 0 & 0 \\
\hline 2 & RASYID & 4 & 0 & 2 & 2 & 0 & 0 & 4 & 0 & 0 \\
\hline 3 & BUJANG & 4 & 2 & 0 & 3 & 0 & 0 & 0 & 2 & 0 \\
\hline 4 & SUPARDI & 4 & 2 & 0 & 2 & 0 & 0 & 4 & 0 & 0 \\
\hline 5 & AFRIZAL & 4 & 0 & 0 & 3 & 0 & 0 & 3 & 0 & 0 \\
\hline
\end{tabular}

Dari nilai awal dari masing-masing calon nasabah tersebut didapatkanlah nilai Gap dari masing-masing calon nasabah dapat dilihat pada tabel 4.5 berikut ini:

Tabel 5 Nilai Gap 


\begin{tabular}{|l|l|l|l|l|l|l|l|l|l|l|}
\hline \multirow{2}{*}{ NO } & \multirow{4}{*}{$\begin{array}{l}\text { NAMA } \\
\text { NASABAH }\end{array}$} & \multicolumn{4}{|l|}{ CHARACTER } & \multicolumn{2}{l|}{ CAPACITY } & \multicolumn{3}{c|}{ CEK } \\
\cline { 3 - 10 } & & A1 & A2 & A3 & B1 & B2 & B3 & C1 & C2 & C3 \\
\hline 1 & ABDUL MUNIR & 0 & -1 & -4 & -3 & -3 & 2 & 2 & -2 & -2 \\
\hline 2 & RASYID & 0 & -4 & -2 & -1 & -3 & -3 & 2 & -2 & -2 \\
\hline 3 & BUJANG & 0 & -2 & -4 & 0 & -3 & -3 & -2 & 0 & -2 \\
\hline 4 & SUPARDI & 0 & -2 & -4 & -1 & -3 & -3 & 2 & -2 & -2 \\
\hline 5 & AFRIZAL & 0 & -4 & -4 & 0 & -3 & -3 & 1 & -2 & -2 \\
\hline
\end{tabular}

Keterangan:

A merupakan kriteria character

A1 yaitu nilai untuk KTP/KK

A2 yaitu ilai untuk Keterangan Domisili

A3 yaitu nilai untuk DLL

B merupakan kriteria capacity

B1 yaitu nilai untuk PNS

B2 yaitu nilai untuk PETANI

B3 yaitu nilai untuk DLL

C merupakan kriteria cek lingkungan

$\mathrm{C} 1$ yaitu nilai untuk SOPAN/KOOPERATIF

$\mathrm{C} 2$ yaitu nilai TIDAK SOPAN

$\mathrm{C} 3$ yaitu nilai untuk DLL

a. Pembobotan

Setelah di peroleh gap dari masing-masing calon nasabah, setiap profil nasabah di beri bobot nilai dengan patokan tabel bobot nilai gap. Pembobotan yang digunakan pada penelitian ini dapat dilihat pada tabel 4.6 berikut ini:

Tabel 6 Pembobotan

\begin{tabular}{|c|c|c|l|}
\hline No & Selisih & $\begin{array}{c}\text { Bobot } \\
\text { Nilai }\end{array}$ & \multicolumn{1}{c|}{ Keterangan } \\
\hline 1 & 0 & 5 & $\begin{array}{l}\text { Tidak ada selisih (Kompetensi sesuai dengan yang } \\
\text { dibutuhkan) }\end{array}$ \\
\hline 2 & 1 & 4,5 & Kompetensi individu kelebihan 1 tingkat/level \\
\hline 3 & -1 & 4 & Kompetensi individu kekurangan 1 tingkat/level \\
\hline
\end{tabular}


Jutnal Ibmiah Metadata, ISSN: 2723-7737, Vol. 2 No. 3 Edisi September 2020 Published: 11-09-2020, Pages: 196-213

DOI: https://doi.org/10.10101/metadata.v2i3

\begin{tabular}{|c|c|c|l|}
\hline 4 & 2 & 3,5 & Kompetensi individu kelebihan 2 tingkat/level \\
\hline 5 & -2 & 3 & Kompetensi individu kekurangan 2 tingkat/level \\
\hline 6 & 3 & 2,5 & Kompetensi individu kelebihan 3 tingkat/level \\
\hline 7 & -3 & 2 & Kompetensi individu kekurangan 3 tingkat/level \\
\hline 8 & 4 & 1,5 & Kompetensi individu kelebihan 4 tingkat/level \\
\hline 9 & -4 & 1 & Kompetensi individu kekurangan 4 tingkat/level \\
\hline
\end{tabular}

Dengan demikian, setiap calon nasabah akan memiliki bobot untuk tiap kriteria seperti pada tabel 4.7 berikut ini:

Tabel 7 Pembobotan Nilai Gap

\begin{tabular}{|l|l|l|l|l|l|l|l|l|l|l|}
\hline \multirow{2}{*}{ NO } & \multirow{2}{*}{$\begin{array}{l}\text { NAMA } \\
\text { NASABAH }\end{array}$} & \multicolumn{3}{|l|}{ CHARACTER } & \multicolumn{3}{|l|}{ CAPACITY } & \multicolumn{4}{|c|}{ CEK } \\
\cline { 3 - 9 } & A1 & A2 & A3 & B1 & B2 & B3 & C1 & C2 & C3 \\
\hline 1 & ABDUL MUNIR & 5 & 4 & 1 & 4.5 & 2 & 2 & 3.5 & 3 & 3 \\
\hline 2 & RASYID & 5 & 1 & 3 & 4 & 2 & 2 & 3.5 & 3 & 3 \\
\hline 3 & BUJANG & 5 & 3 & 1 & 5 & 2 & 2 & 3 & 5 & 2 \\
\hline 4 & SUPARDI & 5 & 3 & 1 & 4 & 2 & 2 & 3.5 & 3 & 3 \\
\hline 5 & AFRIZAL & 5 & 1 & 1 & 5 & 2 & 2 & 4.5 & 3 & 3 \\
\hline
\end{tabular}

b. Perhitungan dan pengelompokan Core Factor dan Secondary Factor dan Nilai Total

1. Perhitungan Core Factor menggunakan rumus:

$\mathrm{NCF}=\frac{\sum \mathrm{NC}}{\sum \mathrm{IC}}$

Keterangan:

NCF : Nilai rata-rata core factor

NC: Jumlah total nila core factor

IC : Jumlah item core factor

2. Perhitungan Secondary Factor menggunkan rumus:

$\mathrm{NRS}=\frac{\sum \mathrm{NS}}{\sum \mathrm{IS}}$

Keterangan: 
NRS : Nilai rata-rata secondary factor

NS : Jumlah total nilai secondary factor

IS : Jumlah item secondary factor

3. Perhitungan Nilai Total menggunakan rumus:

$60 \%(\mathrm{NCF})+40 \%(\mathrm{NSF})=\mathrm{N}$

Keterangan :

$\mathrm{N} \quad$ : Nilai Total dari Aspek

NCF : Nilai Core Factor

NSF : Nilai Secondary Factor

a. Character

* Abdul Munir

NCF $\frac{5+4}{2}=4.5$

NSF $\quad \frac{1}{1}=1$

Nilai Total $60 \% * 4.5+40 \% * 1=3.1$

* Rasyid

NCF $\frac{5+1}{2}=3$

NSF $\frac{3}{1}=3$

Nilai Total $60 \% * 3+40 \% * 3=3$

- Bujang

NCF $\frac{5+3}{2}=4$

NSF $\frac{1}{1}=1$

Nilai Total $60 \% * 4+40 \% * 1=2.8$

* Supardi

NCF $\frac{5+3}{2}=4$

NSF $\frac{1}{\mathbf{1}}=1$

Nilai Total $60 \% * 4+40 \% *=2.8$

- Afrizal

NCF $\frac{5+1}{2}=3$

NSF $\frac{1}{1}=1$

Nilai Total $60 \% * 3+40 \% * 1=2.2$

Tabel 8 Nilai NCF,NSF dan Nilai Total Character

\begin{tabular}{|l|c|l|l|l|c|c|c|}
\hline NO & NAMA SUBJEK & A1 & A2 & A3 & $\begin{array}{c}\text { CORE } \\
\text { FACTOR }\end{array}$ & $\begin{array}{c}\text { SECONDAY } \\
\text { FACTOR }\end{array}$ & $\begin{array}{c}\text { NILAI } \\
\text { TOTAL }\end{array}$ \\
\hline
\end{tabular}


Jutnal Ibniah Metadata, ISSN: 2723-7737, Vol. 2 No. 3 Edisi September 2020 Published: 11-09-2020, Pages: 196-213

DOI: https://doi.org/10.10101/metadata.v2i3

\begin{tabular}{|l|l|c|c|c|c|c|c|}
\hline 1 & ABDUL MUNIR & 5 & 4 & 1 & 4.5 & 1 & 3.1 \\
\hline 2 & RASYID & 5 & 1 & 3 & 3 & 3 & 3 \\
\hline 3 & BUJANG & 5 & 3 & 1 & 4 & 1 & 2.8 \\
\hline 4 & SUPARDI & 5 & 3 & 1 & 4 & 1 & 2.8 \\
\hline 5 & AFRIZAL & 5 & 1 & 1 & 3 & 1 & 2.8 \\
\hline
\end{tabular}

b. Capacity

* Abdul Munir

NCF $\frac{4.5+2}{2}=3.25$

NSF $\frac{2}{1}=2$

Nilai Total $60 \% * 3.25+40 \% * 2=2.75$

* Rasyid

NCF $\frac{4+2}{2}=3$

NSF $\frac{2}{1}=2$

Nilai Total $60 \% * 3+40 \% * 2=2.6$

* Bujang

NCF $\frac{5+2}{2}=3.5$

NSF $\frac{2}{1}=2$

Nilai Total $60 \% * 3.5+40 \% * 2=2.9$

* Supardi

NCF $\frac{4+2}{2}=3$

NSF $\frac{2}{1}=2$

Nilai Total $60 \% * 3.5+40 \% * 2=2.6$

* Afrizal

NCF $\frac{5+2}{2}=3.5$

NSF $\frac{2}{1}=2$

Nilai Total $60 \% * 3.5+40 \% * 2=2.9$

Tabel 9 Nilai NCF,NSF dan Nilai Total Capacity

\begin{tabular}{|l|c|c|c|c|c|c|c|}
\hline NO & NAMA SUBJEK & $\mathrm{A} 1$ & $\mathrm{~A} 2$ & $\mathrm{~A} 3$ & $\begin{array}{c}\text { CORE } \\
\text { FACTOR }\end{array}$ & $\begin{array}{c}\text { SECONDAY } \\
\text { FACTOR }\end{array}$ & $\begin{array}{c}\text { NILAI } \\
\text { TOTAL }\end{array}$ \\
\hline 1 & ABDUL MUNIR & 5 & 2 & 2 & 3.25 & 2 & 2.75 \\
\hline
\end{tabular}


Jutnal Ibniah Metadata, ISSN: 2723-7737, Vol. 2 No. 3 Edisi September 2020 Published: 11-09-2020, Pages: 196-213

DOI: https://doi.org/10.10101/metadata.v2i3

\begin{tabular}{|l|l|c|c|c|c|c|c|}
\hline 2 & RASYID & 4 & 2 & 2 & 3 & 2 & 2.6 \\
\hline 3 & BUJANG & 5 & 3 & 1 & 4 & 2 & 2.9 \\
\hline 4 & SUPARDI & 4 & 3 & 1 & 4 & 2 & 2.6 \\
\hline 5 & AFRIZAL & 5 & 1 & 1 & 3 & 2 & 2.9 \\
\hline
\end{tabular}

c. Cek Lingkungan

* Abdul Munir

NCF $\frac{3.5+3}{2}=3.25$

NSF $\frac{3}{1}=3$

Nilai Total $60 \% * 3.25+40 \% * 3=3.15$

Rasyid

NCF $\frac{3.5+3}{2}=3.25$

NSF $\frac{3}{1}=3$

Nilai Total $60 \% * 3.25+40 \% * 3=3.15$

Bujang

NCF $\frac{3+5}{2}=4$

NSF $\frac{3}{1}=3$

Nilai Total $60 \% * 4+40 \% * 3=3.6$

* Supardi

NCF $\frac{3.5+3}{2}=3.25$

NSF $\frac{3}{1}=3$

Nilai Total $60 \% * 3.25+40 \% * 3=2.15$

Afrizal

NCF $\frac{4.5+3}{2}=3.15$

NSF $\frac{3}{1}=3$

Nilai Total $60 \% * 3.15+40 \% * 3=3.45$

Tabel 10 Nilai NCF,NSF dan Nilai Total Cek Lingkungan

\begin{tabular}{|l|l|c|l|l|c|c|c|}
\hline NO & NAMA SUBJEK & $\mathrm{A} 1$ & $\mathrm{~A} 2$ & $\mathrm{~A} 3$ & $\begin{array}{c}\text { CORE } \\
\text { FACTOR }\end{array}$ & $\begin{array}{c}\text { SECONDAY } \\
\text { FACTOR }\end{array}$ & $\begin{array}{c}\text { NILAI } \\
\text { TOTAL }\end{array}$ \\
\hline 1 & ABDUL MUNIR & 3.5 & 3 & 3 & 3.25 & 3 & 3.5 \\
\hline 2 & RASYID & 3.5 & 3 & 3 & 3.25 & 3 & 3.15 \\
\hline 3 & BUJANG & 3 & 3 & 3 & 4 & 3 & 3.6 \\
\hline
\end{tabular}




\begin{tabular}{|l|l|l|l|l|l|l|l|}
\hline 4 & SUPARDI & 3.5 & 3 & 3 & 3.25 & 3 & 3.15 \\
\hline 5 & AFRIZAL & 4.5 & & 3 & 3.75 & 3 & 3.45 \\
\hline
\end{tabular}

c. Perhitungan Penentuan Ranking Hasil akhir dari pencarian profile matching adalah ranking dari nasabah yang diajuakan untuk menerima kredit sepada motor . Penentuan ranking mengacu pada hasil perhitungan tertentu. Perhitunga tersebut bisa ditunjukkan dengan rumus dibawah ini. Ranking $=50 \% *$ charactre $+30 \% *$ capacity $+20 \% *$ cek lingkungan

\section{* Abdul Munir}

Ranking $=50 \% * 3.1+30 \% * 2.75+20 \% * 3.15=3.01$

\section{* Rasyid}

Ranking $=50 \% * 3+30 \% * 2.6+20 \% * 3.15=2.91$

* Bujang

Ranking $=50 \% * 2.8+30 \% * 2.9+20 \% * 3.6=2.99$

* Supardi

$$
\text { Ranking }=50 \% * 2.8+30 \% * 2.6+20 \% * 3.15=2.81
$$

* Afrizal

$$
\text { Ranking }=50 \% * 2.2+30 \% * 2.9+20 \% * 3.45=2.66
$$

Setelah setiap nasabah mendapatkan nilai akhir, maka bisa ditentukan peringkat atau ranking nasabah berdasarkan pada semakin besarnya hasil niali akhir, maka semakin besar pula kesempatan untuk mendaptkan kredit sepeda motor. Hasil perankingan dapat dilihat pada tabel 4.11 berikut ini:

Tabel 11 Hasil Perangkingan

\begin{tabular}{|c|l|c|c|c|c|}
\hline NO & $\begin{array}{l}\text { NAMA } \\
\text { SUBJEK }\end{array}$ & CHARACTER & CAPACITY & $\begin{array}{c}\text { CEK } \\
\text { LINGKUNGAN }\end{array}$ & $\begin{array}{c}\text { NILIA } \\
\text { AKHIR }\end{array}$ \\
\hline 1 & $\begin{array}{l}\text { ABDUL } \\
\text { MUNIR }\end{array}$ & 3.1 & 2.75 & 3.15 & 3.01 \\
\hline 2 & BUJANG & 2.8 & 2.9 & 3.6 & 2.99 \\
\hline 3 & RASYID & 3 & 2.6 & 3.15 & 2.91 \\
\hline 4 & SUAPRDI & 2.8 & 2.6 & 3.15 & 2.81 \\
\hline 5 & AFRIZAL & 2.2 & 2.9 & 3.45 & 2.66 \\
\hline
\end{tabular}

\section{Implementasi Sistem}

Implementasi sistem merupakan seluruh pemodelan proses dan antarmuka yang dituangkan dalam sebuah bahaha pemogramman untuk mengetahui apakah sistem berjalan sesuai dengan kebutuhan. Perancangan sistem menggunakan model UML (Unified Modelling Language) yang digunakan untuk menggambarkan cara kerja sistem pengambilan keputusan. Setelah perancangan 
sistem selesai maka di lakukan implementasi kedalam program yakni dengan menggunakan bahasa pemrograman PHP dan database MySQL.

Adapun tampilan dari sistem pendukung keputusan menggunakan metode profle matching untuk kelayakan pemberian kredit sepeda motor adalah sebagai berikut.

1. Tampilan Form Login

Dalam kasus ini hanya pegawai yang bertugas sebagai admin dan pengembil keputusan yang dapat mengakses sistem ini. Untuk itu dibuatkan form login yang dapat membatasi pengguna sistem. Dalam hal ini pengguna mengisiskan username dan password dengan benar agar dapat menggunakan sistem pendukung keputusan menggunakan metode profile matching untuk kelayakn pemberian kredit sepeda motor . berikut adalah tampilan menu login.

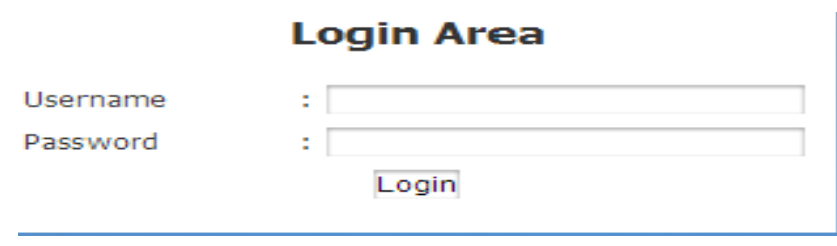

Gambar 1 Implementasi Menu Login

2. Implementasi Menu Utama Admin

Menu utama admin terdiri dari berbagai pilihan menu diantaranya yaitu menu master, menu perangkingan, menu laporan dan menu logout.

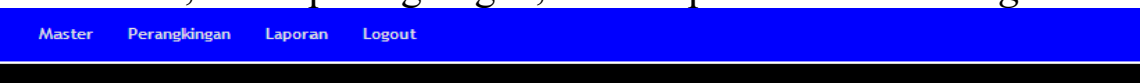

PROFILE MATCHING

Welcome

Gambar 2. Implementasi Menu Utama Admin

3. Implementasi Menu Aspek Penilain

Menu ini berisi informasi tentang aspek atau kriteria-kriteria yang diperlukan dalam proses pengambilan keputusan, seperti aspek character, capacity dan aspek cek lingkungan. 


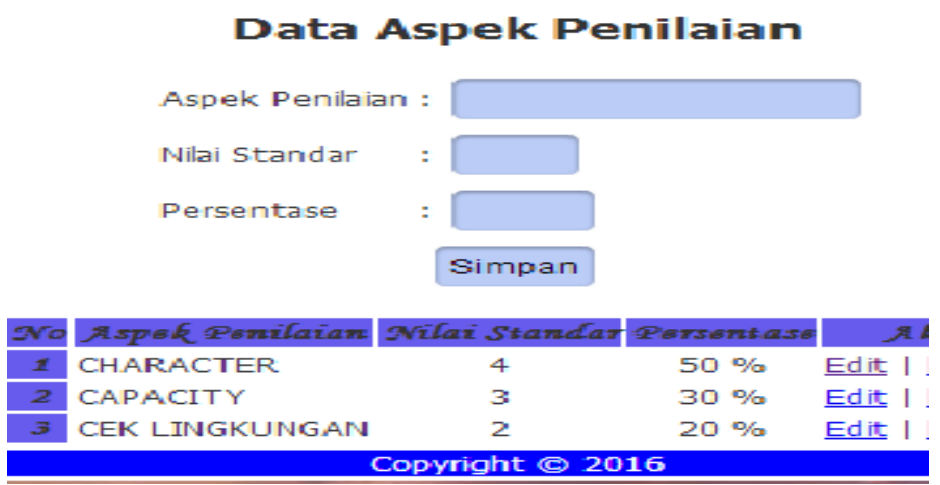

Gambar 3. Implentasi Menu Aspek Penilaian

4. Implentasi Menu Penilaian

Menu ini berisi informasi tentang fakror-faktor dari aspek penilaian dibagi menjadi beberapa sub -sub aspek penilaian sistem pendukung keputusan.

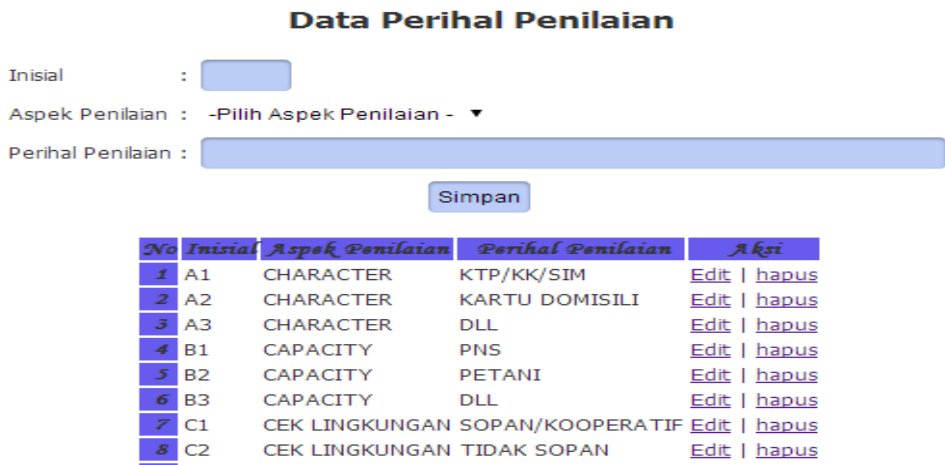

Gambar 4. Implementasi Menu Penilaian

5. Implementasi Menu Data Subjek

Menu ini berisi informasi tentang nama-nama nasabah yang akan diseleksi menjadi nasabah yang akan diberikan kredit sepeda motor.

Data Subjek Penilaian

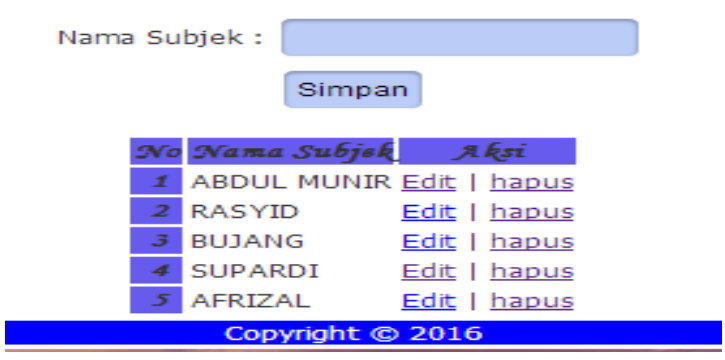

Gambar 5. Implementasi Data Subjek

6. Implemntasi Menu Pembobotan

Menu ini berisi informasi nilai nasabah berdarkan faktor-faktor dari aspek atau kriteria. Nilai dari aspek didapatkan dari hasil interview 
Jutnal Ibniah Metadata, ISSN: 2723-7737, Vol. 2 No. 3 Edisi September 2020 Published: 11-09-2020, Pages: 196-213

DOI: https://doi.org/10.10101/metadata.v2i3

dengan calon nasabah. Nilia pembobotan dapat dilihat pada gambar 5.6 berikut ini:

Pembobotan

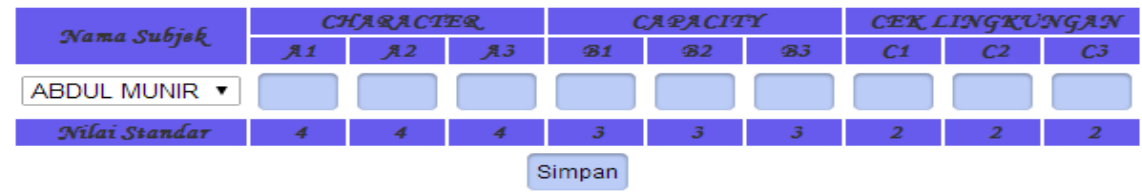

Nilai Pembobotan

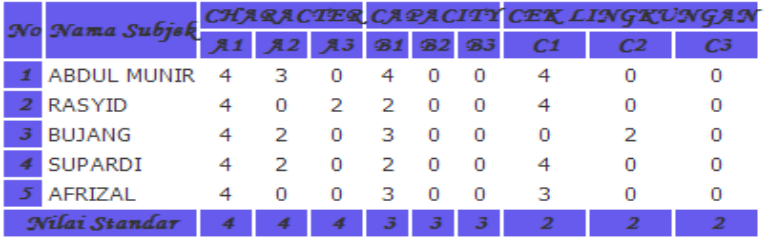

Copyright (c) 2016

Gambar 6. Implemntasi Menu Pembobotan

7. Implementasi Menu Konverisi Pembobotan

Menu ini berisi informasi untuk mendapatkan nilai GAP dan nilai bobot dari masing-masing nasabah.

PROFILE MATCHING

Konfersi Nilai Ke Bobot

Nilaĩ Awal

\begin{tabular}{|c|c|c|c|c|c|c|c|c|c|c|}
\hline & \multirow{2}{*}{ SVama $S u \sigma_{j j}$} & \multicolumn{3}{|c|}{ CFCARACTER } & \multicolumn{3}{|c|}{ Crescrx-2 } & \multicolumn{3}{|c|}{ CER EISVGRUSVGRI } \\
\hline & & g. 1 & 92 & 9.8.3 & 81 & 832 & 83 & $C x$ & $\mathrm{C} 2^{2}$ & $c \mathrm{CB}^{3}$ \\
\hline 1 & ABDUL MUNIR & 4 & 3 & 0 & 4 & 0 & 0 & 4 & 0 & 0 \\
\hline 2 & RASYID & 4 & o & 2 & 2 & o & 0 & 4 & o & 0 \\
\hline 3 & BUJANG & 4 & 2 & $\overline{0}$ & 3 & $\mathrm{o}$ & $\mathrm{o}$ & 0 & 2 & 0 \\
\hline$\overline{4}$ & SUPARDI & 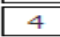 & 2 & 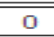 & 2 & 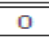 & 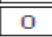 & 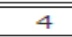 & 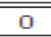 & "0 \\
\hline 5 & AFRIZAL & 4 & 0 & 0 & 3 & 0 & 0 & 3 & 0 & 0 \\
\hline 5 & rifaristardar & 4 & 4 & 4 & 3 & 3 & 3 & 2 & 2 & 2 \\
\hline
\end{tabular}

GAP

\begin{tabular}{|c|c|c|c|c|c|c|c|c|c|c|}
\hline \multirow[b]{2}{*}{$y$} & \multirow{2}{*}{ Pvama subjef } & \multicolumn{3}{|c|}{ cFolqaC } & \multicolumn{3}{|c|}{ 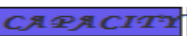 } & \multicolumn{3}{|c|}{ 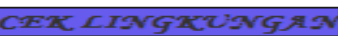 } \\
\hline & & 911 & 92 & R.3 & 81 & 82 & 83 & $\mathrm{C} x$ & $C 2$ & $\mathrm{C} 3^{3}$ \\
\hline 1 & ABDUL MUNIR & o & -1 & -4 & 1 & -3 & -3 & 2 & -2 & -2 \\
\hline 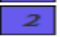 & RASYID & $\overline{0}$ & -4 & -2 & -1 & -3 & -3 & 2 & -2 & -2 \\
\hline 3 & BUJANG & 0 & -2 & -4 & 0 & -3 & -3 & -2 & o & -2 \\
\hline 4 & SUPARDI & o & -2 & -4 & -1 & -3 & -3 & 2 & -2 & -2 \\
\hline 5 & AFRIZAL & 0 & -4 & -4 & 0 & -3 & -3 & & -2 & -2 \\
\hline
\end{tabular}

Kofersi Nilai Ke Bobot

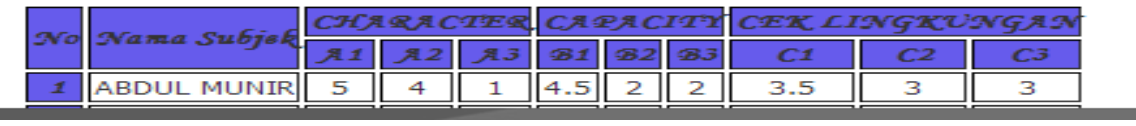

Gambar 7. Implementasi Menu Konversi Pembobotan

8. Implementasi Menu Perhitungan NCF Dan NSF

Menu ini bertujuan untuk mencari nilai NCF (Nilai Core Factot) dan NSF (Nilai Secondary Factor). Dimana nilai dari NCF dan NSF sangat diperlukan untuk mencari nilai total atau nilai akhir. 


\section{PROFILE MATCHING}

\section{Perhitungan Core Factor Dan Secondary Factor}

CHARACTER

\begin{tabular}{|c|c|c|c|c|c|c|c|}
\hline Qve & Sama Subjek & A1 & 92 & A3 & Cors Factor (OVCF) & Secondary Factor (IVSF) & Nifai Total \\
\hline 1 & ABDUL MUNIR & 5 & 4 & 1 & 4.5 & 1 & 3.1 \\
\hline 2 & RASYID & 5 & 1 & 3 & 3 & 3 & 3 \\
\hline 3 & BUJANG & 5 & 3 & 1 & 4 & 1 & 2.8 \\
\hline 4 & SUPARDI & 5 & 3 & 1 & 4 & 1 & 2.8 \\
\hline 5 & AFRIZAL & 5 & 1 & 1 & 3 & 1 & 2.2 \\
\hline
\end{tabular}

CAPACITY

\begin{tabular}{|c|c|c|c|c|c|c|c|}
\hline SNo & Mama Subjek & 81 & 82 & 83 & Cors Factor (PVCF, & Secondary Factor (ONSF, & SVilai Total \\
\hline 1 & ABDUL MUNIR & 4.5 & 2 & 2 & 3.25 & 2 & 2.75 \\
\hline 2 & RASYID & 4 & 2 & 2 & 3 & 2 & 2.6 \\
\hline 3 & BUJANG & 5 & 2 & 2 & 3.5 & 2 & 2.9 \\
\hline 4 & SUPARDI & 4 & 2 & 2 & 3 & 2 & 2.6 \\
\hline 5 & AFRIZAL & 5 & 2 & 2 & 3.5 & 2 & 2.9 \\
\hline
\end{tabular}

CEK LINGKUNGAN

\begin{tabular}{|c|c|c|c|c|c|c|c|}
\hline vo & PVama Subjof & C1 & $C^{2}$ & C.3 & Cors Factor (ONCF) & Secondary Factor (JNSF) & SVílai Totai \\
\hline 1 & ABDUL MUNIR & 3.5 & 3 & 3 & 3.25 & 3 & 3.15 \\
\hline 2 & RASYID & 3.5 & 3 & 3 & 3.25 & 3 & 3.15 \\
\hline 3 & BUJANG & 3 & 5 & 3 & 4 & 3 & 3.6 \\
\hline 4 & SUPARDI & 3.5 & 3 & 3 & 3.25 & 3 & 3.15 \\
\hline 5 & AFRIZAL & 4.5 & 3 & 3 & 3.75 & 3 & 3.45 \\
\hline
\end{tabular}

Gambar 8 Implementasi Menu Perhitungan NCF Dan NSF

9. Implementasi Menu Perhitungan Ranking

Menu ini berisi informasi untuk menghitung nilai yang didaptkan dari masin-masing nasabah kemeudian di menentukan perankingan untuk mendaptkan calon nasabah yang ideal.

\section{PROFILE MATCHING}

\section{Penentuan Ranking}

\begin{tabular}{|c|c|c|c|c|c|}
\hline So & SVana SubjeA & CFARACTEQ & CAPACITY & CEX IISVGXUSVGAJ & Fasil A kfir \\
\hline 1 & ABDUL MUNIR & 3.1 & 2.75 & 3.15 & 3.01 \\
\hline 2 & BUJANG & 2.8 & 2.9 & 3.6 & 2.99 \\
\hline 3 & RASYID & 3 & 2.6 & 3.15 & 2.91 \\
\hline 4 & SUPARDI & 2.8 & 2.6 & 3.15 & 2.81 \\
\hline 5 & AFRIZAL & 2.2 & 2.9 & 3.45 & 2.66 \\
\hline
\end{tabular}

Gambar 9. Implementasi Menu Perhitungan Ranking

10. Implementasi Menu Laporan

Menu ini berisi informasi tentang nasabah yang menerima kelayakan kredit sepeda motor. 


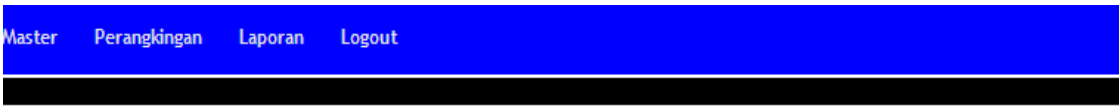

\section{PROFILE MATCHING}

Subjek Yang Layak Mendapatkan Kredit Di Pilih Berdasarkan Nilai tertinggi

\begin{tabular}{|c|c|c|c|c|c|}
\hline & Nama Subjof & CFAQR CTES & CAPACIT & CER LIJGXUJGR, & Fasil A, fhit \\
\hline 1 & ABDUL MUNIR & 3.1 & 2.75 & 3.15 & 3.01 \\
\hline 2 & BUJANG & 2.8 & 2.9 & 3.6 & 2.99 \\
\hline 3 & RASYID & 3 & 2.6 & 3.15 & 2.91 \\
\hline 4 & SUPARDI & 2.8 & 2.6 & 3.15 & 2.81 \\
\hline 5 & AFRIZAL & 2.2 & 2.9 & 3.45 & 2.66 \\
\hline
\end{tabular}

Gambar 10. Implementasi Menu Laporan

\section{Pengujian Sistem}

Pengujian adalah proses eksekus isuatu program untuk menentukan kesalahan yang terjadi pada program tersebut. Untuk proses pengujian diguanakan jenis pengujian blackbox dengan diambil pada form data kriteria.

$P$ roses pengujian sistem menggunakan metode pengujian blackbox dapat dilihat tabel 5.1 berikut ini:

Tabel 12. Hasil Pengujian blackbox

\begin{tabular}{|c|c|c|c|}
\hline Input & Proses & Output & Hasil Pengujian \\
\hline $\begin{array}{l}\text { Tekan tombol } \\
\text { simpan }\end{array}$ & $\begin{array}{l}\text { Melaksankan peoses } \\
\text { penyimpanan data }\end{array}$ & Data akan disimpan & Susuai \\
\hline $\begin{array}{l}\text { Tekan tombol } \\
\text { edit }\end{array}$ & $\begin{array}{l}\text { Melaksanakan } \\
\text { pengeditan data }\end{array}$ & $\begin{array}{lr}\text { Data yang akan } \\
\text { diperbaruhi } \\
\text { yang data baru }\end{array}$ & Sesuai \\
\hline $\begin{array}{l}\text { Tekan tombol } \\
\text { hapus }\end{array}$ & $\begin{array}{ll}\text { Melaksanakan proses } \\
\text { penghapusan data }\end{array}$ & Data akan dihapus & Sesuai \\
\hline $\begin{array}{l}\text { Tekan tombol } \\
\text { logout }\end{array}$ & $\begin{array}{l}\text { Melaksanakan } \\
\text { keluar }\end{array}$ & $\begin{array}{lll}\text { Form data } & \text { akan } \\
\text { ditutup } & & \end{array}$ & Sesuai \\
\hline
\end{tabular}

Black box testing adalah pengujian yang dilakukan hanya mengamati hasil eksekusi melaluli data uji dan fungsional dari perangkat lunak. Jadi dianalogikan seperti kita melihat suatu kotak hitam kita hanya hanya bisa melihat tampilan luarnya saja, tanpa mengetahui ada apa dibalik bungkus hitamnya. Sama seperti pengujian black box, mengevaluasi hanya dari tampilan luarnya atau interfcace, fungsionalitasnya tanpa mengetahui apa sesungguhnya yang terjadi dalam proses detilnya hanya mengetahui (input dan output ).

\section{KESIMPULAN}

Dari analisa dari Sistem Pendukung Keputusan Menggunakan Metode Profile Matching Untuk Kelayakan Pemberian Kredit Sepeda Motor di Adira multifinance Kecamatan IV Jurai Painan dapat diambil kesimpulan sebagai 
berikut: Sistem dari perkreditan di Adira Multifinance Kecamatan IV Jurai Painan yaitu terdiri dari beberapa aspek atau kriteria. Dalam penulisan skripsi ini penulis hanya membuat tiga aspek atau kriteria. Aspek atau krieria tersebut dibagi menjadi beberapa su-sub aspek atau kriteria. Seperti aspek Character terdiri dari $\mathrm{KTP} / \mathrm{KK}$ asli dan berlaku, keterangan domisili asli dan berlaku dll, kemudia aspek Capacity terdiri dari PNS, petani, dll, aspek Cek Lingkungan terdiri dari sopan/kooperatif,tidak sopan, dll. Dengan sistem pendukung keputusan menggunakan metode profile matching berbasis web dapat membantu Credit Marketing Officier untuk memberikan gambaran nasabah yang layak atau tidak untuk mendapatkan kredit sepeda motor. Kerena Credit Marketing Officier telah mengetahu informasi dari calon nasabah berdasarkan pertanyaan yang diajukan berdasarkan aspek dan faktor-faktor yang berkaitan dengan aspek perkreditan. Sistem yang dibuat bisa membantu Credit Marketing officier untuk melakukan penyeleksian untuk beberapa calon nasabah yang mengajukan kredit sepeda motor dalam waktu yang singkat dan cepat.

\section{DAFTAR PUSTAKA}

Kusrini, 2007, Konsep Dan Aplikasi Sistem Pendukung keputusan. Yogyakarta : Andi

M. Shalahuddin Rosa A.S ,2013. Rekayasa Perangkat Lunak Terstruktur dan Berorientasi Objek.Bandung : INFORMATIKA

Mandala, Eka Praja Wiyata, 2015. Web Programming Project 1 “e.pw.m Forum”. Yogyakarta: CV. ANDI OFFSET

Supramono, Gatot, 2009. Perbankan dan Masalah Kredit. Jakarta: Rineka Cipta

Puspitasari, Luckyana, 2013. Penerapan Metode Profile Matching Dalam Sistem

Pendukung Keputusan Penilaian Kinerja Karyawan (Studi Kasus : PT. Perkebunan Nusantara III Medan). ISSN 2301-9425

Faizal, Edi, 2014. Implementasi Metode Profile Matching Untuk Penentuan Penerimaan Usulan Penelitian Internal Dosen STMIK EL RAHMA. ISSN 1979-9330

Muqtadir, Asfan, dkk.2013. Sistem Pendukung Keputusan Kenaikan Jabatan Menggunakan Metode Profile Matching (Studi Kasus : PT. Industri Kemasan Semen Gresik). ISSN 1907-5022 